\title{
An increase in bed temperature on gasification of dual reactor fluidized bed
}

\author{
I Nyoman Suprapta Winaya ${ }^{1, *}$, I Ketut Gede Wirawan ${ }^{1}$, I Wayan Arya Darma $^{3}$, I Putu Lokantara ${ }^{1}$ and Rukmi Sari Hartati ${ }^{2}$ \\ ${ }^{1}$ Study Program of Mechanical Engineering, Udayana University, Bukit Campus Jimbaran Badung-Bali, Indonesia \\ ${ }^{2}$ Study Program of Electrical Engineering, Udayana University, Bukit Campus Jimbaran Badung-Bali, Indonesia \\ ${ }^{3}$ Study Program of Magister in Mechanical Engineering, Udayana University Sudirman Campus Denpasar-Bali Indonesia
}

\begin{abstract}
One of the main issues using biomass as fuel in air gasification is the dilution of its product gas by the nitrogen in the air. A dual reactor fluidized bed (DRFB) overcomes this problem in which the gasification and combustion reactions are decoupled and conducted in two separate fluidized bed reactors connected by circulating bed material. The DFRB unit made of 304 stainless steel pipe with a height of 100 and $150 \mathrm{~cm}$, and inner diameters (i.d.) of 15.2 and $5.1 \mathrm{~cm}$ for gasifier and combustor respectively. The rice husk as fuel and quartz sand as bed material having the same size of $0.4-0.6 \mathrm{~mm}$ were applied in this investigation. Since the gasification process is an endothermic reaction, gasification temperatures are varied at $600^{\circ} \mathrm{C}$ to $700^{\circ} \mathrm{C}$ while combustion reactor were kept at $600^{\circ} \mathrm{C}$ using the electric heaters enclosed in ceramic cover. The superficial gas velocity in this study was kept constant at $17 \mathrm{~m} / \mathrm{s}$ using the external air volumetric flux of the blower flow entering the DRFB loop. Gas gasification samples are then examined by gas chromatography to determine syngas content $\left(\mathrm{CO}, \mathrm{CH}_{4}\right.$ and $\left.\mathrm{H}_{2}\right)$. The test results showed that by the increasing temperature of the gasification reactor there was an increase in syngas especially $\mathrm{CO}$ gas conentration. The temperature increases in the gasification reactor $\left(600^{\circ} \mathrm{C}, 650^{\circ} \mathrm{C}, 700^{\circ} \mathrm{C}\right)$ is able to increase the endothermic reaction in the gasification process which is dominated by $\mathrm{CO}$ gas production. The syngas efficiency was found to increase from $40.95 \%$ to $43.77 \%$. as the temperature of the gasification reactor increased
\end{abstract}

\section{Introduction}

The availability of fossil fuels from the earth continues to decline as the technology using power steadily increases. Many efforts have been made to overcome the energy crisis including developing alternative fuels, which come from renewable energy resources such as biomass. Biomass is defined as a renewable raw materials or organic masses of vegetable or animal origin as well as biowaste from which energy sources can be obtained [1]. Biomass is a non-fossil organic material and biodegradation that can be converted as solid, liquid and gas fuel. The technology of converting biomass into energy can be done by gasification which is considered to be one of the most matured techniques to convert biomass into flammable syngas due to its high conversion efficiency and wide application of the gas [2]. The gasification intrinsically involves a series of reactions including fuel pyrolysis, char gasification, carbon residues combustion and tar cracking/reforming [3]. In dual fluidized bed reactors, gasification and combustion processes are well separated from each other and the heat required by endothermic gasification is obtained from the combustion process through circulation of heated bed materials such as quartz sand.

Research on coal and wood co-gasification in the 100 $\mathrm{kW}$ fluidized bed reactor gasification found that the composition of producer gas varies linearly with linear variations in wood mixing ratios [4]. Research on the temperature at the composition and Lower Heating Value (LHV) of syngas from the fluidized bed gasification reactor found that higher temperature reactions could produce higher $\mathrm{CO}$ content and higher efficiency, but LHV syngas decreased with increasing temperature [5].

High temperatures can also have an effect on producing flammable gases. The temperature in the reactor has a strong effect on the reaction activity that occurs in the reactor [6]. Carbon reacts with carbon dioxide $\left(\mathrm{CO}_{2}\right)$ and water vapor $\left(\mathrm{H}_{2} \mathrm{O}\right)$ is more active at high temperatures. The concentration of carbon monoxide (CO) in the gas heating value and the resulting syngas must increase [7]. Heat is generated in the combustion reactor, the heat released during the oxidation process is used in the drying process, pyrolysis and endothermic reactions that occur in the gasification reactor. In the early stages of previous research the heat generated by the combustion reactor was less able to heat the biomass in the gasification reactor so that the endothermic reaction that occurred was not maximal and would cause a decrease in the resulting syngas content. Therefore, in this study the research on the effect of temperature on the gasification reactor on the syngas gasification content using a dual fluidized bed reactor (DRFB) is carried out. The DRFB is designed for a laboratory scale to have a better understanding on the temperature dependence of gasification temperature.

\footnotetext{
*Corresponding author: ins.winaya@unud.co.id
} 


\section{Metodology}

\subsection{Schematic of Dual Reactor Fluidized Bed (DRFB)}

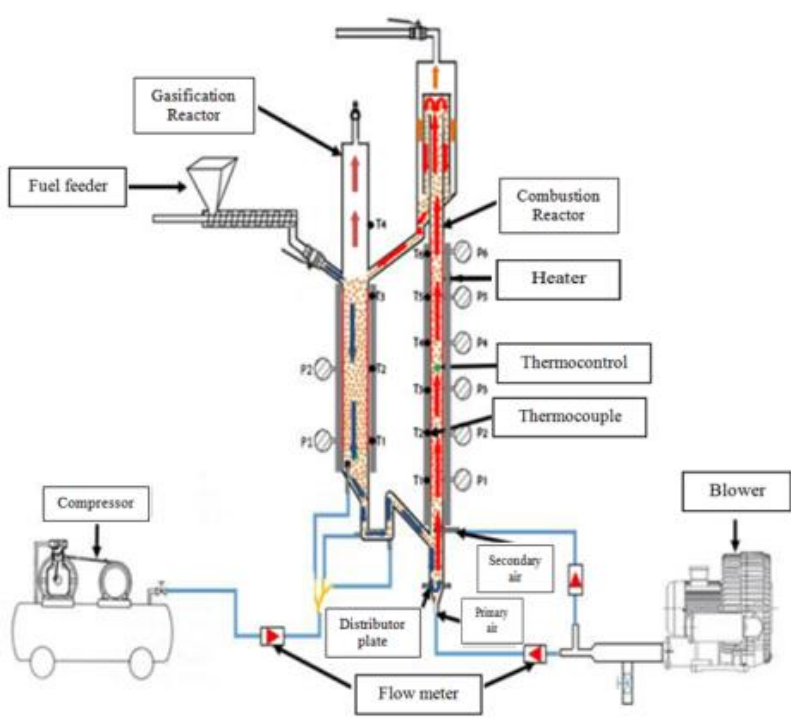

Fig.1. Schematic unit of dual reactor fluidized bed (DRFB) and inserted electrical heater

The schematic principle of DRFB is Figure shown in 1 . It consists mainly of two connected reactors, an endothermic air bubbling fluidized (BB) gasifier and an exothermal circulating fluidised bed (CFB) riser combustor, and has the biomass feed rate of approx. $6 \mathrm{~kg}$ biomass feed per hour. Following the combustor, there is a cyclone to separate the circulating bed material from the flue gas of the combustor to the gasifier reactor, so that the whole reactor DRFB is well isolated from the loss heat to surrounding.

As solid heat carrier, the circulating bed material transfers heat generated from the combustor to provide the energy needed for gasification reactions. The fluidization agent in the gasifier is air and the syngas exits from the top of the gasifier. The residual biomass char is then transferred by bed-material into the combustor through the lower pressure zone. In the combustor, the fluidization agent is air, which results in an oxidation of the char that produces heat at the temperature of $700^{\circ} \mathrm{C}$. The hot bedmaterial separates from the flue gas in the cyclone separator to be recycled into the gasifier through the upper pressure zone, which prevents gas leakage between the separate environments in the gasifier and the combustor. The gasifier is supported by electrical heaters and is heavily insulated. The only heat source for operation is the electrical heaters either for combustion and gasification comes from the electricity source. The gasifier and the combustor have a height of 100 and 150 $\mathrm{cm}$, and inner diameters (i.d.) of 15.2 and $5.1 \mathrm{~cm}$, respectively.

In the combustion reactor is installed six (6) pieces of pressure gauge and 6 thermocouple probes to see the pressure and temperature distribution of the reactor. In the gasification reactor, two (2) pressure gauges and four (4) thermocouples were properly installed. Each reactor is fitted with a thermostat that is useful for regulating the temperature in the reactor to remain constant condition. While the air produced by the compressor is used on the downer section to circulate the bed mixture of the quartz sand bed material and the rice husk biomass into the combustion gasification reactor.

\subsection{Bed Material and Feedstock}

In this study, the heat carrier between the reactors was the bed-material of quartz sand $\left(99.4-99.9 \% \mathrm{SiO}_{2}\right)$ having the particle density of $2.18 \mathrm{gr} / \mathrm{cm}^{3}$ and a small specific heat of $0.20 \mathrm{cal} / \mathrm{gram}^{\circ} \mathrm{C}$. As the quartz sand is non-porous bed material, the smaller the heat value of the material, the easier to increase the temperature $[8,9]$. The quartz sand has a high melting point until it reaches $1800^{\circ} \mathrm{C}$, so it is suitable for fluidized bed gasification applications.

The rice husk was used as the feedstock. Both rice husk and quartz sand used were in the form of fine granules of the same size of $0.4-0.5 \mathrm{~mm}$.

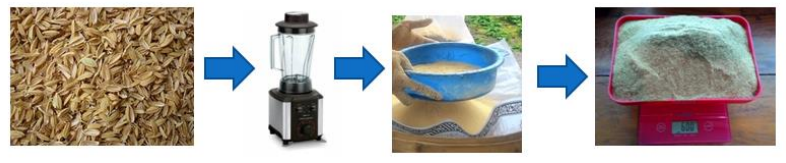

Fig. 2. Rice husk biomass preparation for feedstock

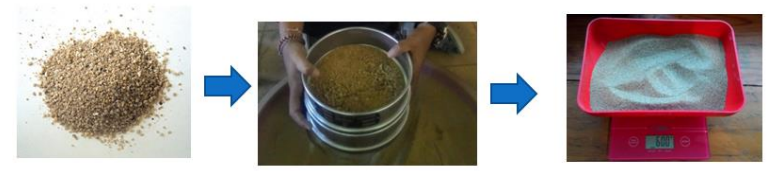

Fig. 3. Quartz sand preparation for bed material

The composition properties of rice husk biomass (as received base) can be determined after proximate and ultimate analysis. The proximate analysis was conducted using the thermo-gravimetric measurement to determine the moisture, ash, volatile and fixed carbon and the ultimate analysis were taken using elemental analyzer to measure the content of carbon, hydrogen, oxygen, nitrogen and sulfur. The results of the analyses were published elsewhere [8].

\subsection{Experimental Procedure}

The gasifier was operated in bubbling fluidized bed (BF) mode while the combustor section was run in circulating fluidized bed (CFB). The quartz sand with an amount of 1000 grams fed into the reactor through the fuel feeder and then the reactor is started to heat until it reaches the required working temperature. The working temperature can be set and seen on the thermo-control box panel. There are two thermo-controls to set the temperature of the gasification and the combustion reactor. The temperature in the combustion reactor is fixed at $700^{\circ} \mathrm{C}$ while the temperature in the gasification reactor is varied. Adjust the air velocity of the blower with an anemometer for primary and secondary flow at $10 \mathrm{~m} / \mathrm{s}$ and $17 \mathrm{~m} / \mathrm{s}$ respectively so that the quartz sand can be circulated. After reaching the steady state condition, the rice husk fuel was continuously fed for amount of 600 grams into 
the gasification reactor through the fuel feeder. The syngas was sampled using a gas storage pipe taken from the gasifier exit and tested using a gas chromatography measurement unit. The tests were repeated for three (3) different temperature variations of the gasification reactor of $600^{\circ} \mathrm{C}$ (I), $650^{\circ} \mathrm{C}$ (II) and $700^{\circ} \mathrm{C}$ (III).

\section{Result and Discussion}

\subsection{Pressure Distribution}

The pressure distribution of each point in the gasification and combustion reactor along the vertical tube was measured continuously along the whole experiments. The installation of a pressure gauge is to determine whether the bed material is circulated properly in the DRFB loop. Referring to the pressure data at several points from Table 1 , it can be described the circulated bed is well operated as seen from the drop pressure of $\mathrm{P}_{1}-\mathrm{P}_{2}$ and $\mathrm{P}_{1}-\mathrm{P}_{6}$ at gasification and combustion section respectively.

Table 1. The pressure profile along vertical tube of gasification and combustion reactor

\begin{tabular}{|c|c|c|c|c|c|c|c|c|}
\hline & \multicolumn{7}{|c|}{ Pressure (mbar) } \\
\hline & $\begin{array}{c}\text { Gasification } \\
\text { Reactor }\end{array}$ & \multicolumn{7}{|c|}{ Combustion Reactor } \\
\hline $\begin{array}{c}\text { Temperature } \\
\left({ }^{\circ} \mathrm{C}\right)\end{array}$ & $\mathrm{P}_{1}$ & $\mathrm{P}_{2}$ & $\mathrm{P}_{1}$ & $\mathrm{P}_{2}$ & $\mathrm{P}_{3}$ & $\mathrm{P}_{4}$ & $\mathrm{P}_{5}$ & $\mathrm{P}_{6}$ \\
\hline 600 & 6.5 & 7.0 & 7.0 & 7.0 & 7.0 & 6.5 & 7.0 & 6.0 \\
\hline 650 & 6.5 & 7.0 & 7.0 & 7.0 & 7.0 & 6.5 & 7.0 & 6.0 \\
\hline 700 & 6.5 & 7.0 & 7.0 & 7.0 & 7.0 & 6.5 & 7.0 & 6.0 \\
\hline
\end{tabular}

\subsection{The Temperature Profile Distribution}

The specific temperature profile of the gasification reactor of DRFB at bed temperature operation of $700^{\circ} \mathrm{C}$ can be seen in Figure 4. Temperatures of $\mathrm{T}_{1}, \mathrm{~T}_{2}$ and $\mathrm{T}_{3}$ are located at dense bed just returning from combustion reactor resulted in higher temperature compared $\mathrm{T}_{4}$ which is in diluted upper section of gasification reactor. The reaction of the main gas formation occurs in the reduction process caused in a decreased gradually in temperature for endothermic reaction reason. Flammable gas in producer gas is formed during the gasification process through the following reaction [1]:

Boudouard Reaction

$\mathrm{C}+\mathrm{CO}_{2} \rightarrow 2 \mathrm{CO}+172 \mathrm{~kJ} / \mathrm{mol}$

Water-Gas Reaction

$\mathrm{C}+\mathrm{H}_{2} \mathrm{O} \rightarrow \mathrm{CO}+\mathrm{H}_{2}+131 \mathrm{~kJ} / \mathrm{mol}$

Water-Gas Shift Reaction

$$
\mathrm{CO}+\mathrm{H}_{2} \mathrm{O} \rightarrow \mathrm{CO}_{2}+\mathrm{H}_{2}-41.2 \mathrm{~kJ} / \mathrm{mol}
$$

Methane Reaction
$\mathrm{C}+2 \mathrm{H}_{2} \rightarrow \mathrm{CH}_{4}-74.8 \mathrm{~kJ} / \mathrm{mol}$

Steam Reforming

$\mathrm{CH}_{4}+\mathrm{H}_{2} \mathrm{O} \rightarrow \mathrm{CO}+3 \mathrm{H}_{2}+206.2 \mathrm{~kJ} / \mathrm{mol}$

Dry Reforming

$$
\mathrm{CH}_{4}+\mathrm{CO}_{2} \rightarrow 2 \mathrm{CO}+2 \mathrm{H}_{2}+247.4 \mathrm{~kJ} / \mathrm{mol}
$$

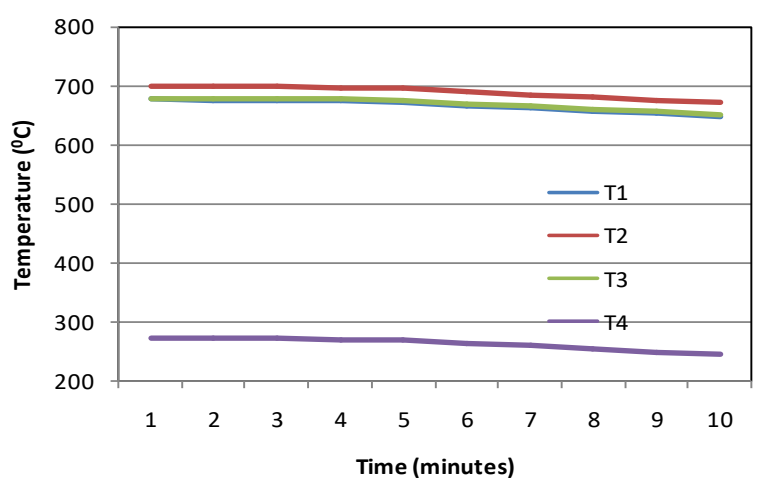

Fig. 4. The profile temperature distribution along vertical bed direction of gasification reactor at $700^{\circ} \mathrm{C}$

The endothermic and exothermic reactions occur during the reduction process in which Boudouard, watergas, steam reforming and dry reforming are the endothermic reactions, while water-gas shift and methane reaction is the exothermic reaction

\subsection{Effect of Temperature on Gasification Syngas Content}

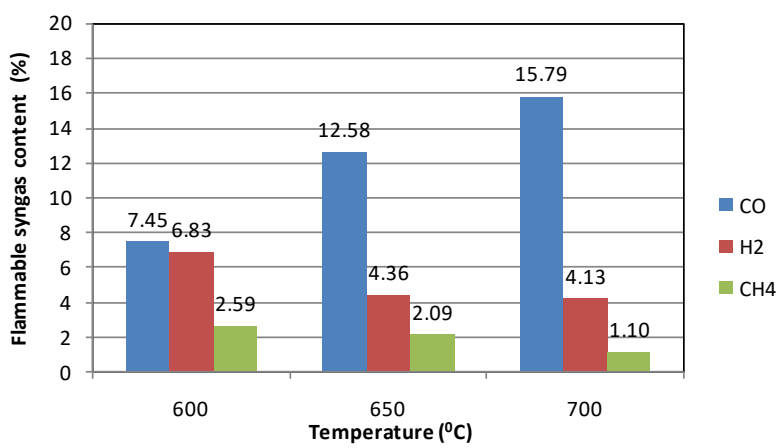

Fig. 5. The flammable syngas content at different elevated gasification bed temperature

The syngas content for a different variation of gasifier temperature of $600^{\circ} \mathrm{C}, 650^{\circ} \mathrm{C}$ and $700^{\circ} \mathrm{C}$ can be seen in Figure 5. As the temperature of the gasification reactor increases, $\mathrm{CO}$ gas production also increases due to an increase in heterogeneous and endothermic reactions such as Boudouard reaction (1) and water-gas reaction () [9]. In other words, at the higher temperature, the carbon tends to react with the steam and $\mathrm{CO}_{2}$ to produce high $\mathrm{CO}$ gas production [10]. The other endothermic reactions causing an increased $\mathrm{CO}$ gas concentration are the reaction between $\mathrm{CH}_{4}$ and $\mathrm{H}_{2} \mathrm{O}$, namely steam reforming (5) and the reaction between $\mathrm{CH}_{4}$ and $\mathrm{CO}_{2}$, namely dry reforming (6) [11]. The test results showed that the 
highest production of $\mathrm{CO}$ gas content was obtained at variation III $\left(700^{\circ} \mathrm{C}\right)$ which was $15.79 \%$ and the lowest in variation $\mathrm{I}\left(600^{\circ} \mathrm{C}\right)$ was $7.45 \%$. The increase in $\mathrm{CO}$ gas is also due to the large amount of the carbon content $(\mathrm{C})$ of the rice husk biomass of $34.03 \%$ as well as $\mathrm{O}_{2}$ composition of $32.68 \%$ so that the rice husk fuel reactivity becomes high when the temperature rises. The methane $\left(\mathrm{CH}_{4}\right)$ gas content is produced due to heterogeneous exothermic in the methane reaction. But along with the increase in temperature in the gasification reactor, the $\mathrm{CH}_{4}$ gas produced reacts (endothermic reaction) with $\mathrm{H}_{2} \mathrm{O}$ and $\mathrm{CO}_{2}$ causing $\mathrm{CH}_{4}$ content to decrease [12]. The test results showed that the highest production of $\mathrm{CH}_{4}$ gas content was obtained in variation I $\left(600^{\circ} \mathrm{C}\right)$ which was $2.59 \%$ and the lowest was in variation III $\left(700^{\circ} \mathrm{C}\right)$ which was $1.10 \%$.

The composition from producer gas depends on the operating temperature of gasification because all chemical reactions in the reactor are temperature dependent. Increasing temperature causes an increase in $\mathrm{H}_{2}$ gas content but the $\mathrm{H}_{2}$ gas begins to decrease at temperatures above $600^{\circ} \mathrm{C}$. The test results showed that the highest production of $\mathrm{H}_{2}$ gas content was obtained in variation I $\left(600^{\circ} \mathrm{C}\right)$ which was $6.83 \%$ and the lowest in variation III $\left(700^{\circ} \mathrm{C}\right)$ was $4.13 \%$. The $\mathrm{CH}_{4}$ gas content increases at $400^{\circ} \mathrm{C}$ and then decreased due to the thermal decomposition of $\mathrm{CH}_{4}$ to $\mathrm{H}_{2}$ and $\mathrm{CO}$. The $\mathrm{CO}$ gas content increases with increasing temperature and the maximum increase in temperatures of $500-700^{\circ} \mathrm{C}$ followed by a decrease in $\mathrm{CO}_{2}$ gas levels [13].

\subsection{Effect of Bed Temperature on Gasification Efficiency}

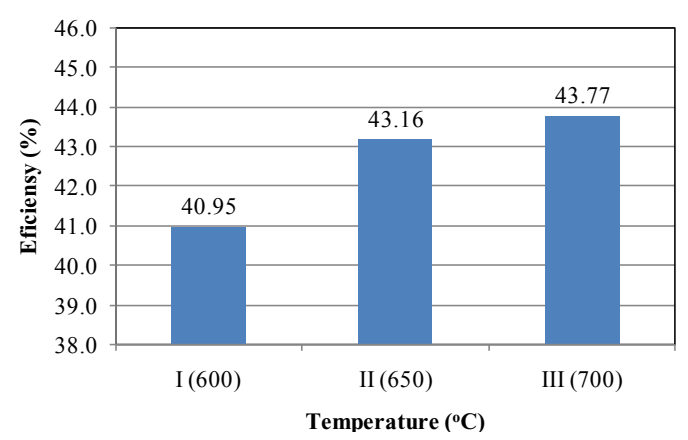

Fig.6. The gasification efficiency of DRFB at different variation of temperature

The graph in Figure 6 shows that the efficiency value increases as the temperature of the gasification reactor increases. The highest efficiency of flammable gas results obtained in this study was at variation III of $43.77 \%$ while the lowest was at variation I of $40.95 \%$. The temperature increases in the gasification reactor is able to increase the endothermic reaction in the gasification process which is dominated by $\mathrm{CO}$ gas production. Although in this test there was a decrease in $\mathrm{CH}_{4}$ and $\mathrm{H}_{2}$ gas content but did not affect in the increase of the total energy from combustible gas/ syngas. The total energy of a syngas increases according to the increase in temperature and later has an effect on increasing efficiency.

\section{Conclusion}

After conducting a series investigations on the effect of temperature variations on the performance of the Dual Reactor Fluidized Bed (DRFB) gasification, the following conclusions can be made:

- The temperature has an effect on the gasification flammable syngas content. The increase temperature of gasification reactor resulted in an increased circulated bed temperature causes in the high endothermic reaction where the carbon content of the rice husk fuel tends to react with $\mathrm{H}_{2} \mathrm{O}$ and $\mathrm{CO}_{2}$ gas causing an increase in $\mathrm{CO}$ and $\mathrm{H}_{2}$ syngas. In the present study by increasing the temperature of gasifier from $600^{\circ} \mathrm{C}$ to $700^{\circ} \mathrm{C}$ the $\mathrm{CO}$ concentration was found to double from $7.45 \%$ to $15.79 \%$.

- The total energy of a syngas increases according to the increase in temperature and later has an effect on increasing efficiency. The higher the temperature in the gasification reactor of $600^{\circ} \mathrm{C}$ to $700^{\circ} \mathrm{C}$, the greater of the syngas efficiency was obtained of $40.95 \%$ to $43.77 \%$ respectively.

The authors would like to forward their gratitude to the University of Udayana Bali and the financial supported from Indonesia's Ministry of Research and Technology through IRPI Grant Contract No.: 54/INS-1/PPK/E4/2018.

\section{Reference}

1. P. Basu, Biomassa Gasification, Pyrolisis and Torefaction Practical Design. Second Edition, USA: Elsevier Inc (2013).

2. A. V. Brightwater, Renewable fuels and chemical by thermal processing of biomass, Chemical Eng. 91 (2003) 87-102

3. Y. Xiao, S. Xu, YB. Song, Y. Shan, C.Wang, G. Wang, Biomass steam gasification for hydrogen-rich gas production in a decoupled dual loop gasification system , Fuel Processing Technology (2017) 54-61

4. I. Aigner, C. Pfeifer, H. Hofbauer, Co-gasification of Coal and Wood in a Dual Fluidized Bed Gasifier. Fuel 90 (2011) 2404-2412.

5. L.Q. Wang, Z.S. Chen, Gas Generation by Cogasification of Biomass and Coal in an Autothermal Fluidized Bed Gasifier. Applied Thermal Engineering, 59 (2013) 278-282.

6. A. Almeida, P. Neto, I. Pereira, A. Ribeiro, R. Pilao, Effect of Temperature on the Gasification of Olive Bagasse Particles. Journal of the Energy Institute, (2017) xxx: 1-8.

7. I.S. Antonopoulos, A. Karagiannidis, A. Gkouletsos, G. Perkoulidis, Modelling of a Downdraft Gasifier Fed by Agricultural Residues. Waste Management, 32 (2012) 710-718.

8. INS. Winaya, RS Hartati, IP Lokantara, IGAN Subawa, IMA Putrawan, Fluidized Bed cogasification of coal and solid waste fuels in air gasifying agent, International Journal of Technology, 6 (2015) 931-937.

9. INS. Winaya, T. Shiizu, Y. Nonaka, K. Yamagiwa, Model of combustion and dispersion of carbon 
deposited on porous bed material during bubbling fluidized bed combustion, 87 (2008), 1974-1981.

10. M. Lapuerta, JJ. Hernandez, A. Pazo, J. Lopez, Gasification and CO-gasification of biomass wastes: effect of the biomass origin and the gasifier operating conditions. Fuel Processing Technology, 89 (2008) 828-837.

11. J. Fermoso, B. Arias, MG. Plaza, C. Pevida, Rubiera F, Pis JJ, High-pressure CO-gasification of Coal with Biomass and Petroleum Coke. Fuel Processing Technology, 90 (2009) 926-932.

12. W. Doherty, A. Reynolds, D. Kennedy, The Effect of Air Preheating in a Biomass CFB Gasifier Using ASPEN Plus Simulation. Biomass Bioenergy, 33 (2009) 1158-1167.

13. DJ. Harris, DG. Roberts, DG.Henderson, Gasification Behaviour of Australian Coals at High Temperature and Pressure. Fuel, 85 (2003) 134-142.

14. V. Dillibabu, E. Natarajan E., Effect of Temperature and Equivalence Ratio on Gasification of Biomass. Journal of Chemical and Pharmaceutical Sciences (2014) 92-94. 